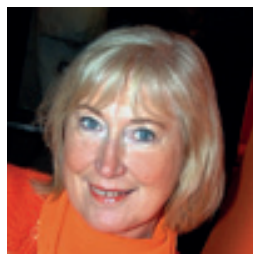

\title{
Når helsepersonell blir pårørende
}

\section{$\AA$ A være helsepersonell og samtidig pårørende er en utfordring som krever god balansekunst.}

Helsepersonell som må forholde seg til en «kollega» som pårørende, opplever nok det samme. For noen år tilbake var jeg på samme tid eneste pårørende til min mann og mine svigerforeldre.

I denne spesielle delen av mitt liv skrev jeg dagbøker. Med «det hele» på avstand har jeg lest notatene på nytt, og ser noen «røde tråder» som kan utledes til noen enkle prinsipper. Det som slår meg er hvor lite som skiller en situasjon fra å være vanskelig til å kunne bli «det gyldne øyeblikk». Og som regel koster det ingen ting og det tar ikke lengre tid.

I nettsøk på begrepet «pårørende» finner jeg mange artikler om pårørende som ressurs. Rolleavklaringen må innebære en avklaring av hvilken ressurs vi er - en ressurs fordi vi kan «overta» noe av jobben, eller en ressurs fordi vi kjenner pasienten godt? Pårørenderollen må være den sentrale. På hvilken måte vi også kan bruke våre kunnskaper, må avklares. Avstanden mellom å bli brukt som en positiv ressurs til følelsen av å bli misbrukt, kan være kort. Hva pasienten ønsker må bety mye i denne sammenheng.

At jeg som pårørende blir sett som en positiv ressurs, har for meg representert mange «gyldne øyeblikk». Likeledes når ansatte viste omsorg for meg i min situasjon. Det var hjemmesykepleieren som ringte og sa: «Anne-Karin, vi ser deg, vi ser hvilke utfordringer du er oppe i. Du skal ikke ha ansvaret for tilbudet til dine svigerforeldre nå, vi tar det. Du skal være svigerdatter, men si fra om det er noe du mener skal endres». Det var legen som på en sen kveld stoppet opp i korridoren, klappet meg på kinnet og sa: «Makter du mer nå?» Så lite, men det betydde alt for meg der og da. Det at han så min situasjon ga meg krefter.

Jeg har erfart hvor lite som skiller en situasjon fra å være vanskelig til at den samme situasjonen kunne blitt et «gyldent øyeblikk». Vi opplevde to stellesituasjoner som i utgangspunktet var helt like, men som for oss (min mann og meg) ble helt forskjellige. Det måtte være to til å stelle, og jeg var alltid den ene når jeg var til stede. Vi ville det slik. Den ene sykepleieren forholdt seg til meg som en ansatt kollega og snakket til min mann som om jeg var en «hvilken som helst» sykepleier. Den andre forholdt seg til meg som en pårørende med en bakgrunn som gjorde at jeg kunne delta i stellet. Hun utviste varhet for min rolle i samarbeidet mellom meg og henne, og på samme tid forholdet mellom meg og min svært syke mann. Den respekt hun viste oss, gjorde at jeg husker dette som «gyldne øyeblikk». Den første situasjonen førte til at vi ble irriterte og fortvilet, den andre ga en følelse av takknemlighet, glede og ro. Et annet «gyldent øyeblikk» var da jeg var på fortvilelsens rand fordi mine observasjoner ikke ble tatt på alvor. En lege kom og «så» det samme som meg, lyttet til hva jeg hadde å si og handlet.

I møte med pasienter og pårørende i krise er det lett å love mye. Etter min manns død ble det sagt: «Du vil høre fra oss.» Jeg hadde i utgangspunktet ingen forventinger, men denne ene setningen ga meg forventinger uten at de ble innfridd. På kort tid hadde jeg også mye kontakt med et begravelsesbyrå. De ga meg «gyldne øyeblikk». Særlig da de ringte den dagen jeg hadde urnenedsettelse for min mann, kun for å si at de tenkte på meg denne dagen. Husket de meg - neppe. De hadde nok skrevet ned at denne dagen måtte de ringe meg. For meg betydde det ingenting om det var deres rutiner som resulterte i oppmerksomheten. Om dere gir lovnader - sørg for å ha rutiner slik at disse kan følges opp.

Som pasient og pårørende vil vi gjerne overholde påbud som blir gitt, for eksempel innen hygiene. Jeg erfarte at leger ikke fulgte de samme prinsippene som vi ble pålagt. Når vi påpekte det, fikk vi svar som «det er ikke så farlig» eller «det går som regel bra». Slike situasjoner skaper utrygghet, ja nesten redsel. At ansatte følger de rutiner de selv har satt opp, er avgjørende for at tillit etableres mellom pasient og personell.

«Åtti prosent av suksess er å være til stede», sa Woody Allen. Dette er noe av det grunnleggende for at møtet mellom pasient/ pårørende $\mathrm{og}$ ansatt kan oppleves som «gyldne øyeblikk» - å oppleve at vi er viktigst der og da, at du ser oss og tar oss på alvor. «Gyldne øyeblikk» var når legen sa: «Anne-Karin du kjenner din mann godt, hva mener du?» Det er godt å bli spurt til råds, men likevel vite at det ikke er jeg som skal fatte beslutningen. God dialog - bare det at du spør - er uttrykk for engasjement, og det er det beste grunnlag for at vi sammen kan skape gode situasjoner.

Jeg håper mine tanker vil inspirere dere til refleksjon og ettertanke i en travel hverdag.

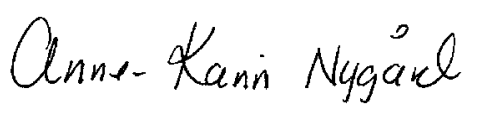

\section{I neste nummer:}

Aktinomykose og spiralbruk

Protonterapi

MR ved skafoidfraktur
Benzodiazepiner ved epilepsi

Hjerteinfarkt 1991-2007

Syfilis og blodtransfusjon 